\title{
Хромосома линии половых клеток зебровой амадины: анализ повторяющихся последовательностей
}

\author{
Давидьян А. ${ }^{1 *}$, Володькина В. ${ }^{1}$, Комиссаров А. ${ }^{2}$, Галкина С. ${ }^{1}$ \\ ${ }^{1}$ Санкт-Петербургский государственный университет, Санкт-Петербург, Россия \\ ${ }^{2}$ Национальный исследовательский университет ИТМО, Санкт-Петербург, Россия \\ *e-mail: asya.davidian@gmail.com
}

Ключевые слова: Taeniopygia guttata, хромосомы типа ламповых щеток, ооцит

Мотивачия и иель: В гаметах зебровой амадины кроме обычных аутосом и половых хромосом ZW $(2 \mathrm{n}=80)$ обязательно присутствует хромосома линии половых клеток (germline-restricted chromosome, GRC) [1]. GRC отсутствует во всех соматических клетках, элиминируется при созревании сперматозоидов и, как следствие, передается только по женской линии. В состав GRC входит $>10 \%$ генома, т.е. $\sim 150$ млн.п.н. [2]. Детального представления о ее роли, поведении в мейозе и эмбриогенезе до сих пор нет. С целью изучения функционирования GRC в оогенезе мы идентифицировали эту хромосому на стадии ламповых щеток (ЛЩ) и выполнили детальный анализ гетерохроматиновых “поясков” - характерных конденсированных участков без боковых петель.

Meтоды и алгоритмы: Морфологическое описание GRC проводили с помощью FISH и иммуноцитохимии с антителами к коилину. Библиотеки для секвенирования из WGA амплифицированного микродиссектированного материала «поясков» готовили с помощью (1) NEBNext Ultra DNA Library Prep Prep и (2) Agencourt AMPure XP с насыщением длинными фрагментами. Секвенирование проводили на Illumina NextSEq 550 в режиме одностороннего прочтения. Сборку контигов осуществляли ассемблером Geneious с высокой чувствительностью (Geneious 9.0). Поиск гомологичных последовательностей в GenBank проводили с помощью BLAST, а известных повторов - используя RepBase (www.girinst.org/censor/).

Результаты: Мы показали, что «пояски» GRC на стадии ЛЩ всегда ассоциированы с внутриядерными коилин-позитивными тельцами. В состав «поясков» входят в основном эндогенные ретровирусы ERV1 и 2, а также ДНК транспозоны, утерявшие способность к транспозиции.

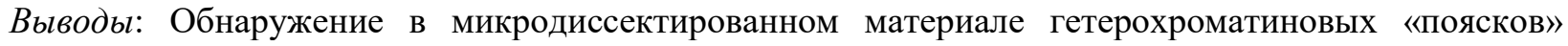
разнообразных рассеянных повторов можно считать парадоксом, так как известно, что на стадии ЛЩ идет активная транскрипция рассеянных повторов с петель [3]. Возможно, что гетерохроматиновая организация этих маркерных для GRC структур (более нигде не встречающихся на ЛЩ) связана с наличием специфических белков, подавляющих деконденсацию хроматина и образование транскрипционно активных петель на стадии ЛЩ.

Благодарности: проф. Н.Б. Рубцову (ИЦиГ СО РАН), РЦ «ЦКП Хромас» СПбГУ, РЦ «Геномика» ИЦиГ СО РАН, РФФИ 20-04-00967.

\section{Список литературы}

1. Pigozzi M.I., Solari A.J. Chrom. Res. 6, 105-113 (1998).

2. Torgasheva A. et al. PNAS. 116, 11845-11850 (2010).

3. Сайфитдинова А.Ф., Галкина С.А., Гагинская Е.Р. Генетика. (2020). В печати. 